\title{
Pyrolytic carbon microelectrodes for impedance based cell sensing
}

Hassan, Yasmin Mohamed; Caviglia, Claudia; Hemanth, Suhith; Mackenzie, David; Petersen, Dirch Hjorth; Keller, Stephan Sylvest

Published in:

Electrochemical Society. Meeting Abstracts (Online)

Publication date:

2016

Document Version

Peer reviewed version

Link back to DTU Orbit

Citation (APA):

Hassan, Y. M., Caviglia, C., Hemanth, S., Mackenzie, D., Petersen, D. H., \& Keller, S. S. (2016). Pyrolytic carbon microelectrodes for impedance based cell sensing. Electrochemical Society. Meeting Abstracts (Online), MA2016-01 . http://ma.ecsdl.org/content/MA2016-01/14/901 .abstract?sid=82478d79-7bb9-4110-b114c331786f4b08

\section{General rights}

Copyright and moral rights for the publications made accessible in the public portal are retained by the authors and/or other copyright owners and it is a condition of accessing publications that users recognise and abide by the legal requirements associated with these rights.

- Users may download and print one copy of any publication from the public portal for the purpose of private study or research.

- You may not further distribute the material or use it for any profit-making activity or commercial gain

- You may freely distribute the URL identifying the publication in the public portal

If you believe that this document breaches copyright please contact us providing details, and we will remove access to the work immediately and investigate your claim 


\title{
Pyrolytic carbon microelectrodes for impedance based cell sensing
}

\author{
Yasmin M. Hassan, Claudia Caviglia, Suhith Hemanth, David Mackenzie, \\ Dirch H. Petersen, Stephan S. Keller
}

\section{${ }^{1}$ Department of Micro- and Nanotechnology, Technical University of Denmark Building 345E, Ørsteds Plads, 2800 Kongens Lyngby}

Conductive carbon structures can be obtained from a polymer template through a pyrolysis process. These structures can be used as electrodes for bio sensing applications such as electrochemical cell morphology evaluation. This study focuses on the optimization of 2D pyrolysed carbon microelectrodes with the carbon MEMS (C-MEMS) process (1), (2). SU-8 was used as photoresist to define the polymer template on a Si-based carrier substrate, and then pyrolysed. Different electrochemical microchips with carbon working (WE) and counter electrode (CE) were fabricated. The particular focus of this work was on the optimization of the pyrolysis process to decrease the resistivity of the resulting carbon material and improve the performance in cyclic voltammetry (CV) and electrochemical impedance spectroscopy (EIS). A gold pseudo-reference electrode (RE) and gold contact pads were deposited by e-beam evaporation through a shadow mask, and a $5 \mu \mathrm{m}$ thick film of SU-8 was used as passivation layer.

To investigate the influence of the different pyrolysis parameters on the obtained carbon, a one-step process was used with a maximum temperature of $900^{\circ} \mathrm{C}$ and a heating rate of $10^{\circ} \mathrm{C} / \mathrm{min}$. Then, the samples were kept at the maximum temperature under $\mathrm{N}_{2}$ for 10 minutes, 1 hour, 2 hours and 10 hours respectively.

Focusing on the influence of the atmosphere during pyrolysis, experiments with different gases were performed, using a one-step process with a dwell time of 1 hour. In particular, the experiments were carried out under $\mathrm{H}_{2}$ and vacuum. The resistivity measurements, performed using a custom made 4-point measurement setup, show that the two hours process in $\mathrm{N}_{2}$ atmosphere gives the lowest resistivity value of $9,32 \times 10^{-3} \Omega \cdot \mathrm{cm}$ (Fig.1a).

For $\mathrm{CV}$, the ferri-ferrocyanide $\left[\mathrm{Fe}(\mathrm{CN})_{6}\right]^{4-} /\left[\mathrm{Fe}(\mathrm{CN})_{6}\right]^{3-}$ redox couple was used, after treatment of the electrodes with oxygen plasma. Also in this case the pyrolysis process of two hours under $\mathrm{N}_{2}$ produced electrodes that displayed the best electrochemical behaviour, with a peak current of $2,88 \times 10^{-4} A$ and a $\Delta E_{p}$ of $240 \mathrm{mV}$ (Fig.1b).

To provide an increased sensitivity for impedance based cell sensing, the design of the electrode chip has been modified. The WE is covered by the passivation layer except for a defined number of small circles with a diameter of $250 \mu \mathrm{m}$ (Fig.1c). The WEs locally increase the current density, and the changes occurring at the multiple WEs dominate the measurement, while the contribution of the CE 
becomes negligible (3). In the previous design with a single WE impedance measurements were not possible.

Electrochemical impedance spectroscopy has been used to monitor adhesion and proliferation of HeLa cells. The experiments have been performed by initially seeding about $7.5 \cdot 10^{4}$ cells into a sterilized batch system containing a laminin coated carbon chip. Dulbecco's Modified Eagle's medium was used as culture medium. The chamber was incubated at $37^{\circ} \mathrm{C}$ in a humidified atmosphere having $5 \% \mathrm{CO}_{2}$.

Impedance spectra were acquired every hour, for 6 hours. $1 \mathrm{mV}$ sinusoidal perturbation potential was applied and 50 points were recorded in the frequency range between $5 \mathrm{~Hz}$ and $300 \mathrm{k} \mathrm{Hz}$. Figure $1 \mathrm{~d}$ shows the comparison between impedance spectra for the electrode with and without cells. As it can be seen, in the frequency range between $1 \times 10^{3}$ and $2 \times 10^{5}$ the impedance variation shows the adhesion of the cells to the substrate.

The results indicate that pyrolysed carbon microelectrodes are suitable for impedance based cell monitoring and that the electrochemical performance can be improved through optimization of the fabrication process and the electrode design.

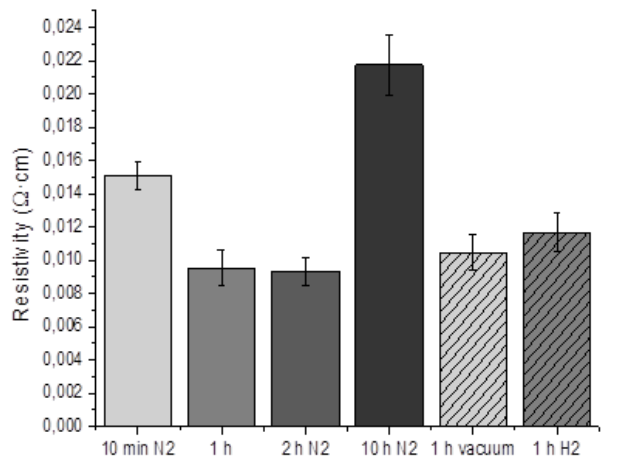

a

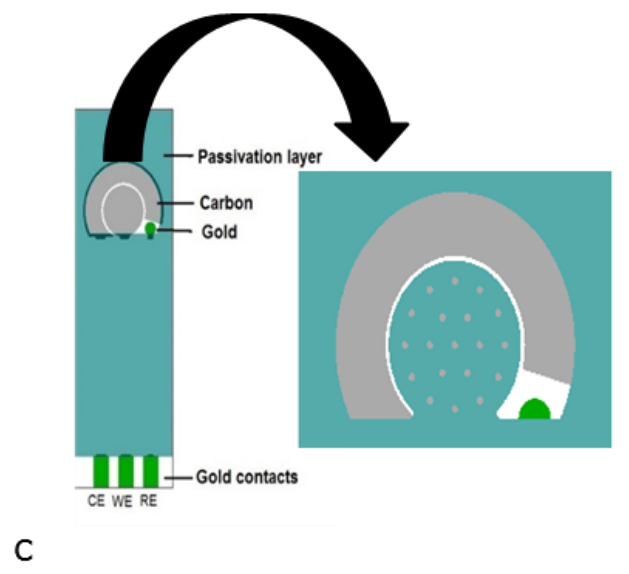

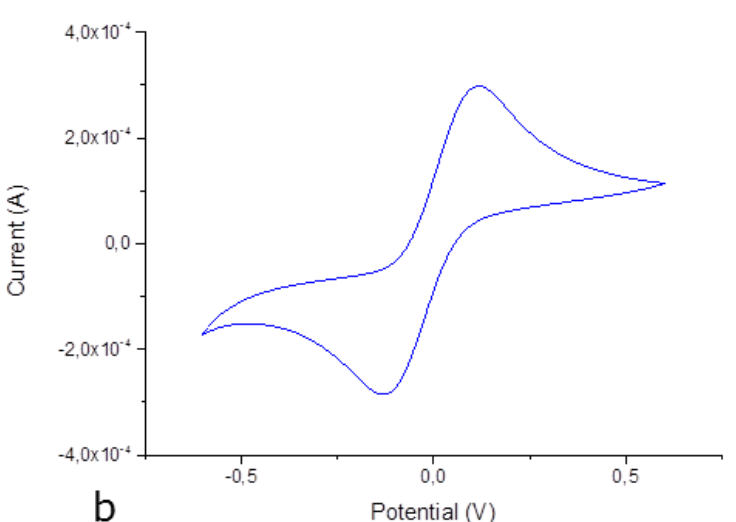

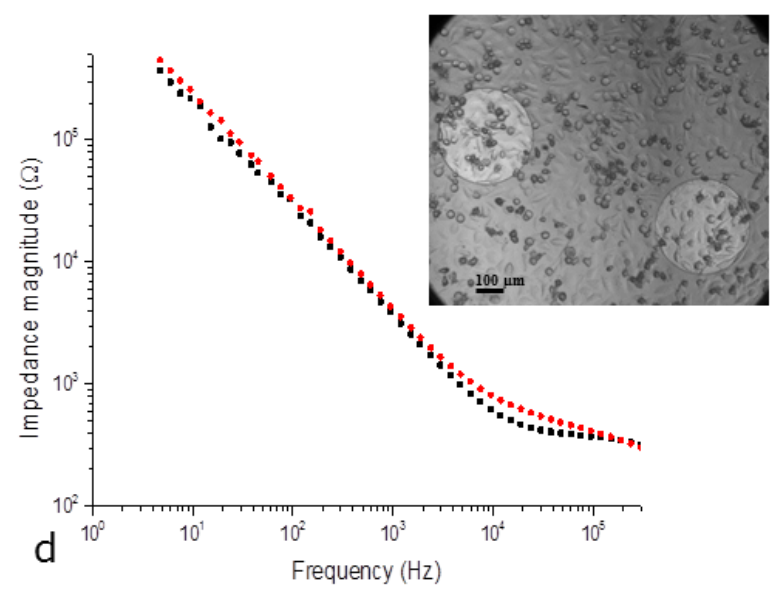

Figure 1: (a) Resistivity values of different pyrolysed carbon microelectrodes, (b) CV voltammogram in ferri-ferrocyanide for a pyrolysed carbon electrode obtained at $900{ }^{\circ} \mathrm{C}$ for 2 hours under $\mathrm{N}_{2}$, (c) electrode design with passivation layer without (left) and with circles (right), (d) compared impedance spectra with (black) and without HeLa cells after 6 hours (red), insert: 
optical microscope image of carbon working electrode with SU-8 passivation layer and circles after cell culturing.

Reference:

1. Singh, A., Jayaram, J., Madou, M., \& Akbar, S. (2002). Pyrolysis of Negative Photoresists to Fabricate Carbon Structures for Microelectromechanical Systems and Electrochemical Applications. Journal of The Electrochemical Society, 149(3), 78-83. http://doi.org/10.1149/1.1436085

2. Wang, C., Jia, G., Taherabadi, L. H., \& Madou, M. J. (2005). A novel method for the fabrication of high-aspect ratio C-MEMS structures. Journal of Microelectromechanical Systems, 14(2), 348-358. http://doi.org/10.1109/JMEMS.2004.839312

3. Stolwijk, J. a, Matrougui, K., Renken, C. W., \& Trebak, M. (2014). Impedance analysis of GPCRmediated changes in endothelial barrier function: overview and fundamental considerations for stable and reproducible measurements. Pflugers Archiv : European Journal of Physiology.

http://doi.org/10.1007/s00424-014-1674-0 